\title{
Extraction of Phenol Compounds in the Liquid Smoke by Pyrolysis of Oil Palm Fronds
}

\author{
Seri Maulina ${ }^{1 *}$, Nurtahara ${ }^{1}$ \\ ${ }^{1}$ Department of Chemical Engineering, Faculty of Engineering, University of Sumatera Utara \\ Jl. Almameter Kampus USU, Medan, 20155, Indonesia \\ *Corresponding Author: maulina_harahap@yahoo.com
}

\section{Article history}

Received: 12-01-2020

Revised: 26-02-2020

Accepted: 15-03-2020

DOI: $10.31629 /$ jit.v1i1.2127

\begin{abstract}
The total content of phenol compounds present in the liquid smoke can be extracted either by using polar or non-polar solvents. Polar and non-polar solvents are often used to extract phenol compounds from plants. Extraction of phenol compounds was performed by using ethyl acetate and hexane solvents at $40{ }^{0} \mathrm{C}, 55{ }^{\circ} \mathrm{C}$ and $70{ }^{\circ} \mathrm{C}$ within 60,120 , and 180 minutes. The highest total content of phenol compounds is $103,394 \mathrm{mg} / \mathrm{g}$ obtained through extraction process at $70{ }^{\circ} \mathrm{C}$ within 180 minutes using ethyl acetate solvent. While, the lowest one is $13,697 \mathrm{mg} / \mathrm{g}$ obtained through extraction process at $40{ }^{0} \mathrm{C}$ within 60 minutes using hexane solvent. The phenol compounds obtained are syringol and guiaicol compounds using ethyl acetate solvent within 180 minutes, at the temperature of $70{ }^{0} \mathrm{C}$, which is $5,44 \%$ and $3,97 \%$.
\end{abstract}

Keywords: pyrolysis, extraction, oil palm fronds, liquid smoke, phenol

\section{Introduction}

Oil palm has nowadays been planted in almost all provinces in Indonesia. In 2015, Sumatera island peaked its oil palm plantation for 7.285.853 ha, with its total amount of production at 21.387.654 tons [1].

Oil palm waste as in empty fruit bunches, trunks, fibers and shells, and fronds are residues of oil palm processing which are still not maximally utilized. As science and technology advance, oil palm waste can be processed into a higher economical product, that is, liquid smoke. Oil palm fronds contain with chemical compounds: cellulose of $26,47 \%$, hemicellulose of $28,43 \%$, lignin $17,65 \%$ [2].

Phenol compounds and their representatives in liquid smoke are affected by lignin compounds and the temperature of pyrolysis. Phenol and its representatives are the result of lignin degradation at the temperature of $400{ }^{\circ} \mathrm{C}$. Basically, any extraction is also affected by temperature and time. The higher the temperature is, the higher the extraction obtained. However, any extraction obtained from various levels of temperature does not differently affect toward its antibacterial properties.

Phenol compounds can be extracted from bio oil by using natrium hydroxide and liquid extraction. Phenol dissolves easily in ethanol, ether, benzene, and some polar or non-polar solvents. In water, phenol compounds have limited solubility and weak acid [3]. Based on this, the research was conducted to find out the effect of solvent, temperature, and extraction 
time on the total of phenol compounds obtained.

\section{Theoretical Background}

Pyrolysis can be defined as thermal decomposition of organic material in inert condition (without the presence of oxygen) that causes the formation of volatile compounds. Pyrolysis up to $170{ }^{\circ} \mathrm{C}$ results in the drying and vaporizing water content, while it results in hemicellulose decomposition at 200-260 ${ }^{0} \mathrm{C}$, cellulose decomposition at $260-310{ }^{\circ} \mathrm{C}$, lignin decomposition at $310-500 \quad{ }^{\circ} \mathrm{C}$, and secondary reactions as oxidation, polymerization and condensation ones at upper $500{ }^{\circ} \mathrm{C}$ [4-5].

The most important cellulose pyrolysis is acetic acid and phenol compounds in a non-substantial amount. Lignin pyrolysis forms distinct flavor in the process of smoked-method products [6-8]. They found out that pyrolysis of coconut shells forms liquid smoke containing 46,56 \% phenol compounds and $12,93 \%$ acid. Besides, there are also groups of liquid smoke components, which are water (11-92 \%), phenol (0,2-2,9\%), acid (2,8-9,5 $\%)$, carbonyl $(2,6-4,0 \%)$ and $\operatorname{tar}(1-7 \%)$ [4].

Phenol compounds are considered to function as antioxidant thus lengthening the expiration date of the smoked-method products. The quantity of phenol compounds on wood is quite various, which is $10-200 \mathrm{mg} / \mathrm{kg}$. Another function is that phenol compounds can add distinct flavors and colors on the processed products. Phenol compounds at a higher boiling point will result in a better antioxidant than ones at a lower boiling point [5].

Extraction of antioxidant is obtained by using organic solvent. Selecting the solvent is based on the polarity of the compounds to isolate. Polar compounds dissolve much easier in polar solvent, while non-polar compounds dissolve much easier in non-polar solvent.

If the temperature is higher and the time is longer, then the total content of phenol compounds is higher. Heightening the temperature and lengthening the time of extraction will increase the solubility of the phenol compounds. Extraction with high temperature will cause the release of cell membrane in phenol compounds due to its damage, thus forming more extracted phenol compounds [6].

This research utilizes liquid smoke as raw materials. Liquid smoke used is obtained from pyrolysis process at $600{ }^{\circ} \mathrm{C}$ as the amount of phenol compounds produces the most at this temperature. Filtering liquid smoke is compulsory to make extraction process easier so as to result in a more efficient total content of phenol compounds. Extraction is carried out by using ethyl acetate and hexane solvents at $40{ }^{\circ} \mathrm{C}, 55{ }^{\circ} \mathrm{C}$, and $70{ }^{\circ} \mathrm{C}$ for 60 , 120, 180 minutes as these conditions enable the extraction to produce phenol compounds in liquid smoke.

\section{Materials and Methods}

The extraction process and the analysis of liquid smoke is to be conducted in the Laboratory of Chemistry and Physics, Department of Chemical Engineering, Faculty of Engineering, University of Sumatera Utara, and the Oil Palm Laboratory and Research Center, Medan.

The extraction apparatus used is a set of reflux condenser equipped with a hot plate heater. For the analysis equipment, analytical balance, graduated cylinder, and other supporting equipment.

The liquid smoke obtained is firstly filtered to deplete the tar. Then, the solvent and the liquid smoke are set. The liquid smoke is dissolved using a measured volume. After that, the mixture is put into the boiling three neck. It is stirred at the speed of stirrer $250 \mathrm{rpm}$ for certain ( $\mathrm{t}$ ) time. The extraction is set at certain (T) temperature. After that, the raffinate and extract phases are removed from separatory funnel, then, the compound is precipitated for 2 hours. Both compounds are put into different Erlenmeyer flasks. Next, the extract phase is to be distilled, then, the volume of its remains in the flasks is measured. Lastly, it is analyzed using Spectrophotometer UV-Visible and GC-MS Shimadzu QP 2100 brands.

\section{Results and Discussion}

This research aims at finding out the result of pyrolysis of oil palm fronds in its liquid smoke form. It is then to be extracted to identify the total content of phenol compounds in it.

The analysis of total content of phenol compounds obtained from liquid smoke extraction of oil palm fronds uses Spectrophotometer UVVisible at the wave length of $701 \mathrm{~nm}$. This length is based on calibration of the previous research. The increase of the total content of phenol resulted from 
this liquid smoke extraction of oil palm fronds can be seen at Figure 1 for different solvent.

Figure 1 shows the effects of time, temperature, and kinds of solvent toward the total content of phenol compounds of liquid smoke. Overall, the total content of phenol compounds increases at a constant time, be as ethyl acetate or hexane solvent.

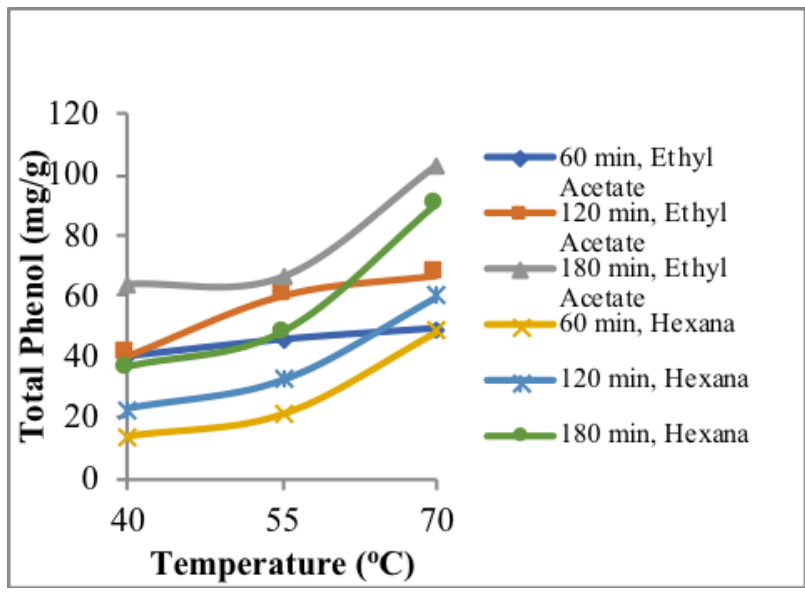

Figure 1. Graphic showing the Effects of kinds of Solvent, Time, and Temperature toward the Total Phenol.

The same thing applies on the increase of time extraction at a constant temperature. The total content of phenol compounds at $70{ }^{\circ} \mathrm{C}$ and time needed $(60 ; 120 ; 180)$ minutes. The result of total content of phenol compounds obtained using ethyl acetate solvent is $49,455 \mathrm{mg} / \mathrm{g} ; 67,333$ $\mathrm{mg} / \mathrm{g} ; 103,394 \mathrm{mg} / \mathrm{g}$ and the result using hexane is $48,949 \mathrm{mg} / \mathrm{g} ; 60,162 \mathrm{mg} / \mathrm{g} ; 90,768 \mathrm{mg} / \mathrm{g}$.

The higher the time extraction spent, the bigger the total content of phenol compounds solved, the bigger the total content of phenol compounds. The interaction between solvent and time shows that the extraction increases at each solvent used.

Based on the previous research, the extraction using water solvent for $6 ; 12 ; 24$ hours result in the amount of total content of phenol compounds for $6,12 \mathrm{~g} ; 6,99 \mathrm{~g} ; 7,89 \mathrm{~g}$. It shows that as time spent increases, and so does the extracted compounds [6].

By increasing the temperature of extraction, the solubility of phenol will also increase. By doing this, the extraction will work efficiently as it decreases the solvent viscosity so as to make phenol compounds easier to be extracted into the solvent [7].

Still, based on the previous research, extraction using ethanol at $25{ }^{0} \mathrm{C} ; 40{ }^{0} \mathrm{C} ; 50{ }^{0} \mathrm{C}$; $60{ }^{0} \mathrm{C} ; 70{ }^{0} \mathrm{C} ; 80{ }^{0} \mathrm{C}$ results in total content of phenol compounds for $70,77 \mathrm{mg} / \mathrm{g} ; 83,94 \mathrm{mg} / \mathrm{g}$; $97,88 \mathrm{mg} / \mathrm{g} ; 110,16 \mathrm{mg} / \mathrm{g} ; 116,88 \mathrm{mg} / \mathrm{g} ; 129,59$ $\mathrm{mg} / \mathrm{g}$. This research proves that the increase of temperature results in the increase of total content of phenol compounds.

The result obtained shows that ethyl acetate is more capable for extracting phenol compounds. Phenol is prone to be polar, much more soluble in ethyl acetate than hexane solvent.

The best condition for extraction process is at $70{ }^{0} \mathrm{C}$, for 3 hours spent to result in the highest total content of phenol compounds, that is, $103,394 \mathrm{mg} / \mathrm{g}$ or $10,339 \%$, while the lowest is at $40{ }^{\circ} \mathrm{C}$, for 1 hour to result in $40,162 \mathrm{mg} / \mathrm{g}$ or $4,016 \%$ using ethyl acetate solvent. When using hexane solvent, the highest total phenol compounds at $70{ }^{\circ} \mathrm{C}$, for 3 hours spent is 90,768 $\mathrm{mg} / \mathrm{g}$ or $9,077 \%$, while the lowest at $40{ }^{\circ} \mathrm{C}$, for 1 hour spent is $13,697 \mathrm{mg} / \mathrm{g}$ or $1,370 \%$.

\subsection{Analysis of Phenol Compounds}

Table 1. Compounds resulted from phenol compounds analysis at liquid smoke extraction for 180 minutes using GC-MS

\begin{tabular}{|c|c|c|c|c|c|}
\hline \multirow[b]{2}{*}{ No } & \multirow[b]{2}{*}{ Solvent } & \multirow{2}{*}{$\begin{array}{l}\text { Kinds of } \\
\text { Compound }\end{array}$} & \multicolumn{3}{|c|}{ Area (\%) } \\
\hline & & & $\begin{array}{l}\text { Temp. } \\
40^{\circ} \mathrm{C}\end{array}$ & $\begin{array}{l}\text { Temp. } \\
55^{\circ} \mathrm{C}\end{array}$ & $\begin{array}{l}\text { Temp. } \\
70^{\circ} \mathrm{C}\end{array}$ \\
\hline 1 & \multirow{3}{*}{$\begin{array}{l}\text { Ethyl } \\
\text { Acetate }\end{array}$} & $\begin{array}{c}\text { Phenol } \\
(\mathrm{CAS}) \text { Izal }\end{array}$ & 43,22 & 47,94 & 52,51 \\
\hline 2 & & $\begin{array}{l}\text { Phenol, 2- } \\
\text { Methoxy- } \\
\text { (CAS) } \\
\text { Guaiacol }\end{array}$ & 3,43 & 3,65 & 3,97 \\
\hline 3 & & $\begin{array}{l}\text { Phenol, 2,6- } \\
\text { Dimethoxy- } \\
\text { (CAS) }\end{array}$ & 4,25 & 4,73 & 5,44 \\
\hline 4 & \multirow{3}{*}{ Hexane } & $\begin{array}{c}\text { Phenol } \\
\text { (CAS) Izal }\end{array}$ & 13,35 & 15,34 & 19,55 \\
\hline 5 & & $\begin{array}{l}\text { Phenol, 2- } \\
\text { Methoxy- } \\
\text { (CAS) } \\
\text { Guaiacol }\end{array}$ & - & - & - \\
\hline 6 & & $\begin{array}{l}\text { Phenol, 2,6- } \\
\text { Dimethoxy- } \\
\text { (CAS) }\end{array}$ & - & - & - \\
\hline
\end{tabular}

Syringol and guaiacol contents are two of the parameters used to determine the quality of liquid smoke functioning as antioxidant [7]. Referring to the testing on the extraction of liquid smoke 
resulted from the using of GC-MS, the result of syringol compound obtained is bigger than the guaiacol one as seen in Table 1 .

Table 1 indicates that Syringol and Guaiacol compounds are resulted from the extraction of liquid smoke by pyrolysis process at $600{ }^{\circ} \mathrm{C}$ for 90 minutes. The best duration of extraction process is 3 hours at $40 ; 55 ; 70{ }^{\circ} \mathrm{C}$. The Table shows that the content of syringol and guaiacol using ethyl acetate solvent increases as the extraction temperature does, too. The increase of extraction temperature will also raise the solubility of phenol compound and release its damage cells [8-9]. In contrast, the content of phenol compounds decreases as it uses hexane solvent. From here, the properties of hexane are identified less capable for extracting phenol compounds in liquid smoke due to its non-polar property.

Any solvents with different polarity give significant effect toward the efficiency of extracting phenol compounds. The solubility of phenol compounds in the solvents depends on the compounds of hydroxyl, the length of hydrocarbon chains and the size of molecule. The bigger the size molecule, the more difficult phenol will solve.

Based on the previous research, by setting at 25 ${ }^{0} \mathrm{C}$ and $60{ }^{\circ} \mathrm{C}$ phenol compounds obtained increases as the temperature raises at $21,24 \%$ and $49,2 \%$. In this research, the temperature set was $40 ; 55 ; 70{ }^{\circ} \mathrm{C}$, which obtained a bigger content of phenol compound for 43,22 \%; 47,94\%; 52,51\% using ethyl acetate solvent and 13,35\%; 15,34\%; 19,55 $\%$ using hexane solvent, as the higher the temperature, the phenol compound extracted also gets higher. From the explanation above, extraction method using ethyl acetate solvent results in a bigger amount of syringol and guaiacol than hexane solvent, that is, $5,44 \%$ and $3,97 \%$ at $70{ }^{\circ} \mathrm{C}$ for 3 hours. On the contrary, hexane solvent cannot extract syringol and guaiacol compounds.

\section{Conclusion}

The highest total content of phenol compounds, which is $103,394 \mathrm{mg} / \mathrm{g}$, is obtained from the extraction process at $70{ }^{\circ} \mathrm{C}$ for 180 minutes using ethyl acetate solvent. While, the lowest one using hexane solvent at $40{ }^{0} \mathrm{C}$ for 60 minutes is 13,697 $\mathrm{mg} / \mathrm{g}$. The higher the temperature, the longer the time, then the higher the total content of phenol compounds is. Syringol and guaiacol compounds as antioxidant at its highest result using ethyl acetate solvent at extraction temperature of $70{ }^{\circ} \mathrm{C}$ and time spent for 3 hours is $5,44 \%$ and $3,97 \%$, while hexane solvent cannot extract syringol and guaiacol compounds.

\section{References}

[1] BPS, Statistik Kelapa Sawit Indonesia. Badan Pusat Statistik, 2016.

[2] S. Maulina, Nurtahara, and Fakhradila. 2018. Pirolisis Pelepah Kelapa Sawit Untuk Menghasilkan Fenol pada Asap Cair. Jurnal Teknik Kimia USU. Vol 7, No 2 , pp 12-16. https://doi.org/10.32734/jtk.v7i2.164

[3] C. Sun, Z. Wu, Z. Wang, and H. Zhang. 2015. Effect of Ethanol/Water Solvents on Phenolic Profiles and Antioxidant Properties of Beijing Propolis Extracts. Evidence-based Complement. Altern. Med., vol. 2015, pp. 1-9.

[4] S. A. Novita, M. E. Djinis, S. Melly, and S. K. Putri. 2014. Processing Coconut Fiber and Shell to Biodiesel. Int. J. Adv. Sci. Eng. Inf. Technol., vol. 4, no. 5, pp. 386-388.

[5] A. Akbar, R. Paindoman, and P. Coniwanti. 2013. Pengaruh Variabel Waktu dan Temperatur terhadap Pembuatan Asap Cair dari Kayu Pelawan (Cyanometra cauliflora). J. Tek. Kim., vol. 19, no. 1, pp. 1-8.

[6] B. Druzynka, A. Stepniewska, and R. Wolosiak. 2007. The Influence of Time and Type of Solvent on Efficiency of The Extraction of Polyphenols from Green Tea and Antioxidant Properties Obtained Extracts. Acta Sci. Pol., Tecnol. Aliment., vol. 6, no. 2, pp. 29-40.

[7] T. Sharmin et al. 2016. Extraction of Bioactive Compound from Some Fruits and Vegetables (Pomegranate Peel, Carrot and Tomato). Am. J. Food Nutr., vol. 4, no. 1, pp. 8-19.

[8] S. Butsat and S. Siriamornpun. 2016. Effect of Solvent Types and Extraction Times on Phenolic and Flavonoid Contents and Antioxidant Activity in Leaf Extracts of Amomum Chinense C. Int. Food Res. J., vol. 23, no. 1, pp. 180-187.

[9] A. Bucić-Kojić, M. Planinić, S. Tomas, L. Jakobek, and M. Šeruga. 2009. Influence of Solvent and Temperature on Extraction of Phenolic Compounds from Grape Seed, Antioxidant Activity and Colour of Extract. Int. J. Food Sci. Technol., vol. 44, no. 12, pp. 2394-2401. 